\title{
HUBUNGAN MINAT BELAJAR DENGAN HASIL BELAJAR MATEMATIKA SISWA KELAS XI.IPA.2 SMAN 1 MUARO JAMBI SEMESTER GANJIL TAHUN PELAJARAN 2019-2020
}

\author{
YUDI WIJAYA \\ SMA Negeri 1 Muaro Jambi Provinsi Jambi \\ Email : yudiwijaya1967@gmail.com
}

\begin{abstract}
ABSTRAK
Penelitian yang dilakukan di SMA Negeri 1 Muaro Jambi ini dilatarbelakangi oleh rendahnya minat belajar siswa dalam proses pembelajaran matematika. Rendahnya minat belajar siswa dalam proses pembelajaran matematika akan berakibat pada rendahnya hasil belajar matematika siswa. Penelitian ini bertujuan untuk melihat apakah ada hubungan antara minat belajar dengan hasil belajar matematika siswa kelas XI.IPA.2 SMA Negeri 1 Muaro Jambi Semester Ganjil Tahun Pelajaran 2019/2020. Jenis penelitian ini adalah penelitian korelasional yaitu penelitian yang bertujuan untuk melihat hubungan antara dua gejala atau lebih. Subjek dalam penelitian ini adalah siswa kelas XI.IPA.2 SMA Negeri 1 Muaro Jambi semester ganjil Tahun Pelajaran 2019/2020 dengan jumlah populasi sebanyak 32 orang siswa. Instrument penelitian yang digunakan untuk memperoleh data adalah dengan menggunakan angket (kuesioner) dalam bentuk pilihan ganda. Pengolahan data dilakukan dengan analisis korelasi spearman. Variabel yang diteliti dalam penelitian ini adalah minat belajar (X) dan hasil belajar (Y). Hasil penelitian untuk mengetahui hubungan antara minat belajar dengan hasil belajar matematika siswa kelas XI.IPA.2 SMA Negeri 1 Muaro Jambi yaitu sebesar 0,3751 dengan koefisien korelasi sebesar 14,07\%. Artinya, hubungan antara minat belajar dengan hasil belajar matematika siswa hanya sebesar $14,07 \%$. Berdasarkan hasil analisis data dapat disimpulkan bahwa terdapat hubungan antara minat belajar dengan hasil belajar matematika siswa kelas XI.IPA.2 SMA Negeri 1 Muaro Jambi Tahun Pelajaran 2019/2020.
\end{abstract}

Kata Kunci:minat belajar, hasil belajar, matematika.

\section{PENDAHULUAN}

Perkembangan ilmu pengetahuan dan teknologi pada saat ini menuntut tersedianya sumber daya manusia yang handal dan mampu berkompetisi secara global. Salah satu upaya untuk menyediakan sumber daya manusia yang demikian adalah melalui jalur pendidikan. Melalui pendidikan manusia menerima dan melakukan perubahan sehingga tingkah lakunya berkembang sebagai proses pembentukan kepribadian, oleh karenanya pendidikan diartikan sebagai suatu kegiatan yang tersusun secara sistematis dan terstruktur pada terbentuknya kepribadian siswa (Jamun, 2018).

Matematika adalah salah satu ilmu dasar yang mempunyai peranan penting dalam dunia pendidikan, sehingga perlu diberikan kepada siswa yang dimulai dari jenjang pendidikan dasar (Rahayu, dkk, 2019). Hal ini sejalan dengan tujuan pembelajaran matematika bahwa mata pelajaran matematika perlu diberikan kepada semua siswa mulai dari sekolah dasar untuk membekali siswa dengan kemampuan berpikir logis, analitis, sistematis, kritis, dan kreatif, serta berkemampuan bekerjasama (Manullang, 2016).

Pendidikan berarti menyangkut proses pembelajaran dan semua faktor yang mempengaruhinya. Salah satu faktor yang dapat mempengaruhi proses pembelajaran adalah minat belajar. Minat merupakan aspek yang sangat penting dalam proses pembelajaran, sebab minat dapat memberikan semangat terhadap seorang siswa dalam kegiatan belajarnya (Ardyani, 2014). Hal ini dapat diasumsikan bahwa dalam belajar seorang siswa harus diberi minat dengan berbagai cara agar tujuan dalam pembelajaran tersebut dapat dicapai. Sirait (2016) memaparkan bahwa dalam kegiatan belajar, minat merupakan daya penggerak di dalam diri siswa yang menimbulkan kegiatan belajar, yang menjamin kelangsungan kegiatan belajar dan yang memberikan arah pada kegiatan belajar, sehingga tujuan yang dikehendaki oleh subjek belajar 
itu tercapai. Artinya, siswa yang memiliki minat kuat akan mempunyai banyak energi untuk melakukan kegiatan belajar. Dalam proses pembelajaran, seorang guru haruslah dapat memperhatikan siswanya, sehingga dirinya dapat memberikan minat terhadap siswanya dalam usaha untuk membantu mengembangkan dirinya (Fadillah, 2016).

Mata pelajaran matematika pada umumnya tidak disukai dan ditakuti karena dianggap sukar oleh siswa, sehingga hal ini dapat mempengaruhi perkembangan belajar matematika siswa dan menurunnya minat belajar siswa dalam pembelajaran matematika. Kesulitan belajar matematika terutama disebabkan oleh sifat khusus dari matematika yang memiliki obyek abstrak. Pembelajaran matematika yang berjalan saat ini cenderung ditujukan pada keterampilan siswa mengerjakan dan menyelesaikan soal-soal matematika. Banyak siswa secara individual kurang memahami konsep matematika, sehingga siswa kurang terminat terhadap pembelajaran matematika (Anjarsari, 2019).

Sekarang ini masih banyak ditemui siswa yang memiliki minat rendah dalam belajar matematika, terutama disekolah. Siswa yang memiliki minat rendah dalam belajar matematika salah satunya dipengaruhi oleh strategi yang digunakan guru dalam proses pembelajaran yang bersifat monoton. Rendahnya minat belajar matematika siswa akan berakibat pada rendahnya hasil belajar matematika siswa. Hasil belajar matematika yang diharapkan adalah hasil belajar yang mencapai ketuntasan belajar matematika (Nasution, 2018). Siswa dikatakan tuntas belajar matematika apabila hasil belajar matematika siswa tersebut telah mencapai kriteria ketuntasan minimum (KKM) yang ditetapkan sekolah (Hermawati, dkk, 2018). Hal inilah yang sering terjadi di sekolah-sekolah, khususnya di SMA Negeri 1 Muaro Jambi Provinsi Jambi Semester Ganjil Tahun Pelajaran 2019/2020.

Membangun minat belajar penting, artinya dalam proses pembelajaran karena fungsinya mendorong, menggerakkan, dan mengarahkan kegiatan belajar. Minat adalah prasyarat dalam pembelajaran, tanpa minat hasil belajar yang dicapai tidak akan optimal dan minat sendiri merupakan dorongan yang timbul dari dalam diri sendiri atau ditimbulkan oleh lingkungan sekitar. Minat yang ada pada seseorang akan mewujudkan suatu perilaku yang diarahkan pada tujuan untuk mencapai sasaran (Nurhasanah, 2016). Keberhasilan belajar seseorang tidak lepas dari minat orang yang bersangkutan, oleh karena itu pada dasarnya minat belajar merupakan faktor yang sangat menentukan keberhasilan belajar seseorang.

Minat merupakan faktor-faktor penggerak maupun dorongan yang dapat memicu timbulnya rasa semangat dan juga mampu merubah tingkah laku manusia atau individu. Minat belajar adalah proses yang memberikan semangat belajar, arah dan kegigihan prilaku terhadap mata pelajaran. Mc. Donald dalam Sardiman (2012:73) mengemukakan bahwa minat adalah perubahan energy dalam diri seseorang yang ditandai dalam munculnya feeling dan didahului dengan tanggapan terhadap adanya tujuan. Dengan adanya minat akan dapat meningkatkan, memperkuat, dan mengarahkan proses belajarnya sehingga akan diperoleh keefektifan belajar lainnya.

Fungsi minat belajar menurut Sardiman (2012:84) ada tiga, yaitu: (1) Mendorong timbulnya kelakuan atau suatu perbuatan. Tanpa minat, tidak akan timbul suatu perbuatan, seperti belajar (2) Minat berfungsi sebagai pengarah. Artinya, minat mengarahkan perbuatan untuk mencapai tujuan yang diinginkan (3) minat berfungsi sebagai penggerak. Minat berfungsi sebagai mobil. Besar kecilnya minat akan menentukan cepat atau lambatnya suatu perbuatan.

Adapun jenis dari minat ada dua yaitu minat instrinsik dan minat ekstrinsik. Minat instrinsik adalah motif-motif yang menjadi aktif atau berfungsinya tidak perlu diransang dari luar, karena dalam diri setiap individu sudah ada dorongan untuk melakukan sesuatu. Minat ekstrinsik adalah motif-motif yang aktif atau berfungsinya karena adanya perangsang dari luar, misalnya dari lingkungan keluarga, masyarakat, guru, orang tua, teman, dll (Abadi, 2020). Pandangan atau persepsi dari masyarakat terhadap matematika bahwa matematika itu sulit juga berdampak pada minat siswa terhadap pembelajaran matematika. Pengalaman pembelajaran matematika dari jenjang sebelumnya juga sangat berpengaruh terhadap minat siswa. Siswa 
tidak akan terminat jika pembelajaran matematika dalam jenjang sebelumnya tidak berjalan dengan baik (Khairina, dkk, 2017).

Siswa yang terminat dapat dilihat dari ciri-ciri siswa tersebut. Adapun cirri-ciri siswa yang memiliki minat dalam belajar adalah ; (1) Tekun menghadapi tugas (dapat bekerja terus menerus dalam waktu yang lama tidak pernah berhenti sebelum selesai) (2) Ulet menghadapi kesulitan (tidak lekas putus asa) tidak memerlukan dorongan dari luar untuk berhasil sebaik mungkin (tidak cepat puas dengan hasil yang telah dicapainya) (3) Menunjukkan minat terhadap bermacam-macam masalah (4) Lebih senang bekerja mandiri (5) Cepat bosan pada tugas-tugas yang rutin (hal-hal yang bersifat mekanis, berulang-ulang begitu saja sehingga kurang kreatif) (6) Dapat mempertahankan pendapatnya (7) Tidak mudah melepaskan hal yang diyakini (8) Senang memecahkan masalah soal-soal (Tafonao, 2018).

Hasil belajar adalah hasil yang diperoleh siswa setelah proses pembelajaran dilaksanakan. Hasil belajar merupakan tolak ukur yang digunakan untuk menentukan tingkat keberhasilan siswa dalam mengetahui dan memahami suatu mata pelajaran (Setiawan, 2019). Sudjana (2004) mengatakan bahwa "hasil belajar adalah kemampuan yang dimiliki siswa setelah ia menerima pengalaman belajarnya". Hasil belajar terwujud dalam tingkah laku dari tidak tahu menjadi tahu, dan dari tidak mengerti menjadi mengerti.

Hasil belajar merupakan tolak ukur yang digunakan untuk menentukan tingkat keberhasilan siswa dalam mengetahui dan memahami suatu mata pelajaran. Hasil belajar dapat berupa keterampilan, nilai dan sikap setelah siswa mengalami proses pembelajaran. Menurut Sudjana (2009), "Hasil belajar adalah kemampuan-kemampuan yang dimiliki siswa setelah ia menerima pengalaman belajarnya. Hasil peristiwa belajar dapat muncul dalam berbagai jenis perubahan atau pembuktian tingkah laku seseorang".

Hasil belajar pada diri seseorang ditandai dengan adanya perubahan tingkah laku, yang dapat diamati dan diukur dalam bentuk perubahan pengetahuan sikap dan keterampilan. Hamalik (2002) menyatakan bahwa "Perubahan disini dapat diartikan terjadinya peningkatan dan pengemabngan yang lebih baik dibandingkan dengan sebelumnya, misalnya dari tidak tau menjadi tidak tau". Hasil belajar dapat diketahui setelah diadakan evaluasi. Salah satu cara yang dapat dilakukan untuk mengetahui tingkat keberhasilan belajar adalah menggunakan tes. Tes ini digunakan untuk menilai hasil belajar yang dicapai dalam meteri pelajaran yang diberikan oleh guru di sekolah. Hasil tes ini kemudian dianalisis oleh guru dan diberikan penilaian. Hasil belajar yang dicapai diharapkan mempunyai efek yang bagus terhadap peningkatan hasil belajar.

Penelitian ini bertujuan untuk melihat apakah terdapat hubungan minat belajar dengan hasil belajar matematika siswa kelas XI.IPA.2 SMA Negeri 1 Muaro Jambi Semester Ganjil Tahun Pelajaran 2019/2020.

\section{METODE PENELITIAN}

Jenis penelitian ini adalah penelitian korelasional. Penelitian korelasional adalah penelitian yang bertujuan untuk melihat hubungan antara dua gejala atau lebih (Hadi, dkk, 1998:52). Metode penelitian ini diharapkan dapat menemukan hubungan antara variablevariabel yang diteliti yaitu minat belajar dengan hasil belajar matematika siswa.

Populasi adalah keseluruhan subjek penelitian. Populasi dalam penelitian ini adalah seluruh siswa kelas XI.IPA.2 SMA Negeri 1 Muaro Jambi yang berjumlah 32 orang. Pengambilan sampel dilakukan dengan teknik total sampling, sehingga yang menjadi sampel dari penelitian ini adalah seluruh siswa kelas XI.IPA.2 SMA Negeri 1 Muaro Jambi.

Instrumen yang digunakan adalah berupa angket dan dokumentasi. Angket berupa daftar pernyatan yang telah disediakan jawabannya. Teknik pengolahan data yang digunakan adalah; a) scoring yaitu memberikan bobot nilai untuk setiap pernyataan angket. Kategori penskoran untuk altervative jawaban angket minat belajar matematika siswa di adopsi dari skala Likert; b) tabulating yaitu mentabulasi data jawaban yang telah diberikan ke dalam bentuk table selanjutnya dinyatakan dalam bentuk frekuensi dan persentase. Dokumentasi yaitu 
pengambilan data yang diperoleh melalui dokumen-dokumen (Hadi, dkk, 1998:110). Dokumentasi dilakukan untuk melihat nilai ujian tengah semester 1 mata pelajaran matematika siswa kelas XI.IPA.2 SMA Negeri 1 Muaro Jambi. Analisis data menggunakan uji t, dengan terlebih dahulu mencari seberapa kuat korelasi antara minat belajar dan hasil belajar matematika siswa menggunakan korelasi Rank Spearman.

\section{HASIL DAN PEMBAHASAN}

Setelah penelitian dilapangan selesai, selanjutnya data hasil penelitian dianalisis untuk mengungkapkan bagaimana hubungan minat belajar dengan hasil belajar matematika siswa. Angket diberikan pada siswa kelas XI.IPA.2 SMA Negeri 1 Muaro Jambi. Siswa yang mengisi angket minat belajar ini ada 26 orang siswa.

Hasil angket dimasukkan dalam tabulasi yang merupakan proses mengolah data dan instrument pengumpulan data (angket). Berdasarkan skor instrument minat belajar dengan hasil belajar matematika siswa, kita dapat mengetahui indikator mana yang lebih dominan memiliki hubungan antara minat belajar dengan hasil belajar matematika. Dari jawaban responden, diperoleh data yang memilih untuk indikator pertama yaitu tekun dalam menghadapi tugas sebanyak 282. Untuk indikator kedua yaitu ulet menghadapi kesulitan sebanyak 229. Indikator ketiga yaitu menunjukkan minat terhadap bermacam-macam masalah sebanyak 288 . Indikator keempat yaitu lebih senang bekerja sendiri sebanyak 170. Indikator kelima yaitu cepat bosan pada tugas-tugas yang rutin sebanyak 236. Indikator keenam yaitu dapat mempertahankan pendapatnya sebanyak 282. Indikator ketujuh yaitu tidak mudah melepaskan hal yang diyakini sebanyak 290, sedangkan untuk indikator kedelapan yaitu senang mencari dan memecahkan masalah sebanyak 219. Sementara jumlah seluruh alternative sebanyak 1996.

Untuk kedelapan indikator tersebut proporsi responden dapat kita tentukan dengan

menggunakan rumus : $\mathrm{P}=\mathrm{x} 100 \%$; dengan $f=$ jumlah total alternative jawaban yang dipilih dan $n=$ jumlah keseluruhan alternative jawaban. Proporsi responden bertujuan untuk mencari presentase responden yang memberikan jawaban pada setiap alternative jawaban disetiap pertanyaan atau pernyataan (Siregar, 2011:193).

Berdasarkan rumus tersebut kita dapat mencari presentase kedelapan indikator minat belajar. Untuk indikator satu diperoleh $14,13 \%$, indikator dua diperoleh $11,47 \%$, indikator tiga diperoleh $14,43 \%$, indikator empat diperoleh $8,52 \%$, indikator lima diperoleh $11,82 \%$, indikator enam diperoleh $14,13 \%$, indikator tujuh diperoleh $14,53 \%$, dan indikator delapan diperoleh $10,97 \%$.

Teknik pengumpulan data yang kedua adalah dokumentasi. Dokumentasi yaitu pengambilan data yang diperoleh melalui dokumen-dokumen (Hadi, 1998:10). Dokumentasi ini dilakukan untuk melihat nilai ujian mid semester I mata pelajaran matematika siswa kelas XI.IPA.2 SMA Negeri 1 Muaro Jambi Tahun Pelajaran 2019/2020. Untuk melihat hasil belajar matematika siswa, maka nilai ujian tengah semester tersebut harus dirangking terlebih dahulu. Berdasarkan perengkingan diperoleh siswa yang berada pada peringkat pertama berjumlah 6 orang, peringkat kedua 3 orang, peringkat ketiga 2 orang, peringkat keempat 2 orang, peringkat kelima 3 orang, peringkat keenam 2 orang, peringkat ketujuh 5 orang, peringkat kedelapan 1 orang, peringkat kesembilan 1 orang, peringkat kesepuluh 1 orang, peringkat kesebelas 1 orang, peringkat keduabelas 3 orang dan peringkat ketigabelas 2 orang. Jadi, total keseluruhan siswa berjumlah 32 orang.

Untuk melihat apakah ada hubungan antara dua variabel yang diteliti yaitu, minat belajar sebagai variabel $\mathrm{X}$ dan hasil belajar sebagai variabel $\mathrm{Y}$, maka dilakukan uji korelasi. Namun, sebelum dihitung korelasinya, nilai mid semester I terlebih dahulu dirangking. Berdasarkan perhitungan dengan menggunakan rumus korelasi Spearman Rank yaitu : $\mathrm{r}=$ $\frac{6 \sum d^{2}}{n\left(n^{2}-1\right)}$

(Riduwan, 2007:74), maka diperoleh angka nilai koefisien korelasi antara minat belajar dengan hasil belajar matematika siswa sebesar 0,3751. Untuk mengetahui apakah ada 
hubungan antara minat belajar dengan hasil belajar, maka nilai $\mathrm{r}_{\text {hitung }}$ dibandingkan dengan nilai $\mathrm{r}_{\text {tabel. }}$ Sebelum membandingkannya, terlebih dahulu dicari statistic uji t. Berdasarkan hasil perhitungan maka diperoleh statistic uji $\mathrm{t}=1,983$ pada taraf kepercayaan $\alpha=0,05$ dan derajat kebebasan $=\mathrm{n}-2=26-2=24$, maka diperoleh $\mathrm{t}_{\text {tabel }}=\mathrm{t}_{(1-\alpha)(\mathrm{n}-2)}=1,711$. Ternyata $\mathrm{t}_{\text {hitung }}$ lebih besar dari $t_{\text {tabel }}$ atau 1,983 > 1,711. Ini berarti $\mathrm{H}_{\mathrm{a}}$ diterima dan $\mathrm{H}_{\mathrm{o}}$ ditolak, dengan kata lain ada hubungan yang signifikan antara minat belajar dengan hasil belajar matematika siswa kelas XI.IPA.2 SMA Negeri 1 Muaro Jambi dengan koefisien determinasi sebesar $\mathrm{R}=\mathrm{r}^{2} \mathrm{x} 100 \%=$ $0,3751^{2} \times 100 \%=14,07 \%$ artinya hubungan antara minat belajar dengan hasil belajar matematika siswa hanya sebesar $14,07 \%$, dengan kata lain minat memberikan kontribusi terhadap hasil belajar matematika siswa sebesar $14,07 \%$.

Berdasarkan hasil penelitian yang telah dilakukan dapat dilihat adanya hubungan minat belajar dengan hasil belajar matematika siswa kelas XI.IPA.2 SMA Negeri 1 Muaro Jambi. Jadi, dapat disimpulkan bahwa terdapat hubungan antara minat belajar dengan hasil belajar matematika siswa. Dengan demikian hipotesis yang diajukan yaitu adanya hubungan minat belajar dengan hasil belajar matematika siswa kelas XI.IPA.2 SMA Negeri 1 Muaro Jambi dapat diterima.

Minat sangat penting dalam belajar, sehingga siswa menjadi tekun dalam proses pembelajaran. Dengan adanya minat belajar kualitas hasil belajar siswa dapat dicapai dengan baik, khususnya pada pembelajaran matematika. Siswa yang mempunyai minat belajar akan tekun dan rajin dalam mengikuti pelajaran yang disampaikan oleh guru. Berdasarkan hasil penelitian ini dapat disimpulkan bahwa terdapat hubungan antara minat belajar dengan hasil belajar matematika siswa.

Minat belajar menjadi salah satu factor penyebab keberhasilan suatu program pendidikan. Dengan tindakan tentang persiapan mengajar, pelaksanaan belajar mengajar, maka guru menguatkan minat belajar siswa. Sebaliknya, dilihat dari segi emansipasi kemandirian siswa, minat belajar semakin meningkat pada saat tercapainya hasil belajar. Minat belajar merupakan segi kejiwaan yang mengalami perkembangan, siswa yang berminat tinggi dalam belajar akan memiliki hasil belajar yang tinggi pula.

Mengingat pentingnya minat terhadap peningkatan belajar siswa maka guru hendaknya membangkitkan minat belajar siswa karena tanpa minat belajar, hasil belajar yang dicapai akan minimum sekali. Guru selalu ingat betapa pentingnya memberikan alasanalasan kepada siswa mengapa siswa-siswa itu harus belajar dengan sungguh-sungguh dan berusaha untuk berprestasi dengan sebaik-baiknya.

\section{KESIMPULAN}

Penelitian ini merupakan penelitian korelasional, dimana penelitian ini bertujuan untuk menemukan hubungan antara variabel-variabel yang diteliti yaitu minat belajar siswa dengan hasil belajar matematika siswa. Berdasarkan hasil analisis data yang telah dilakukan maka dapat disimpulkan bahwa ada hubungan antara minat belajar dengan hasil belajar matematika siswa kelas XI.IPA.2 SMA Negeri 1 Muaro Jambi Semester Ganjil Tahun Pelajaran 2019-2020 yaitu sebesar 0,3751 dengan koefisien korelasi sebesar 14,07\%. Artinya, hubungan antara minat belajar dengan hasil belajar matematika siswa hanya sebesar 14,07\%.

\section{DAFTAR PUSTAKA}

Abadi, A. P. (2020). Minat Belajar Siswa Dalam Pembelajaran Matematika. Prosiding Sesiomadika, 2(1d).

Anjarsari, E. (2019). Faktor permasalahan pendekatan saintifik 5M dalam pembelajaran Matematika di SMA. Vygotsky: Jurnal Pendidikan Matematika dan Matematika, 1(1), 12-20.

Ardyani, A. (2014). Analisis faktor-faktor yang mempengaruhi minat mahasiswa menjadi guru Akuntansi pada mahasiswa prodi pendidikan akuntansi angkatan 2010 Universitas Negeri Semarang. Economic Education Analysis Journal, 3(2). 
Fadillah, A. (2016). Analisis minat belajar dan bakat terhadap hasil belajar matematika siswa. Mathline: Jurnal Matematika dan Pendidikan Matematika, 1(2), 113-122.

Hadi, Amirul dan Haryono. (1998). Metodologi Penelitian Pendidikan. Pustaka Setia: Bandung

Hamalik, Oemar. (2002). Kurikulum dan Pembelajaran. Jakarta: Bumi Aksara

Hermawati, H., Nurcahyono, N. A., \& Setiani, A. (2018). Proses Pelaksanaan Remedial Teaching Terhadap Ketuntasan Belajar Matematika Siswa. SOSIOHUMANIORA: Jurnal Ilmiah Ilmu Sosial Dan Humaniora, 4(2).

Jamun, Y. M. (2018). Dampak teknologi terhadap pendidikan. Jurnal Pendidikan dan Kebudayaan Missio, 10(1), 48-52.

KHairina, R. M., \& Syafrina, A. (2017). Hubungan antara minat belajar dengan hasil belajar siswa dalam mata pelajaran IPA pada kelas V SD Negeri Garot Geuceu Aceh Besar. Jurnal Ilmiah Mahasiswa Pendidikan Guru Sekolah Dasar, 2(1).

Manullang, M. M. M. (2016). Manajemen pembelajaran matematika. Jurnal Pendidikan Dan Pembelajaran (JPP), 21(2), 208-214.

Nasution, M. K. (2018). Penggunaan metode pembelajaran dalam peningkatan hasil belajar siswa. Studia Didaktika, 11(01), 9-16.

Nurhasanah, S., \& Sobandi, A. (2016). Minat belajar sebagai determinan hasil belajar siswa. Jurnal Pendidikan Manajemen Perkantoran (JPManper), 1(1), 128-135.

Rahayu, L. D., \& Kusuma, A. B. (2019). Peran Pendidikan Matematika di Era Globalisasi. Prosiding Sendika, 5(1).

Sardiman. (2012). Interaksi dan Minat Belajar Mengajar. Jakarta: Rajawali Pers

Setiawan, A. R. (2019). Penggunaan Mabadi „Asyroh dalam Pembelajaran Biologi untuk Meningkatkan Minat dan Hasil Belajar. In Prosiding Seminar Nasional Biologi (pp. 158-164).

Sirait, E. D. (2016). Pengaruh minat belajar terhadap hasil Belajar Matematika. Formatif: Jurnal Ilmiah Pendidikan MIPA, 6(1).

Siregar, Syofian. (2011). Statistika Deskriptif Untuk Penelitian. Jakarta: Raja Grafindo Persada.

Sudjana, Nana. (2004). Landasan Psikologi Pendidikan. Bandung: Remaja Rosdakarya

Sudjana, Nana. (2009). Penilaian Hasil Proses Belajar Mengajar. Bandung: Remaja Rosdakarya

Tafonao, T. (2018). Peranan media pembelajaran dalam meningkatkan minat belajar mahasiswa. Jurnal Komunikasi Pendidikan, 2(2), 103-114. 